\title{
A Study on Work Autonomy of Public Servant in China
}

\author{
Haibo Yu, Ran An, Bingtao Zhu \\ Beijing Normal University, Beijing, China \\ Email: anranlunwen@163.com
}

How to cite this paper: Yu, H.B., An, R. and Zhu, B.T. (2017) A Study on Work Autonomy of Public Servant in China. Open Journal of Social Sciences, 5, 282-288. https://doi.org/10.4236/jss.2017.55020

Received: April 2, 2017

Accepted: May 20, 2017

Published: May 23, 2017

Copyright $\odot 2017$ by authors and Scientific Research Publishing Inc. This work is licensed under the Creative Commons Attribution International License (CC BY 4.0).

http://creativecommons.org/licenses/by/4.0/

\begin{abstract}
Public service motivation is an emerging focus in recent years. From the perspective of public service motivation theory, this study investigated the possible influencing factors of public service motivation. Based on a sample of 382 public servants through questionnaire survey, we got a result that work autonomy is significantly correlated with public service motivation.
\end{abstract}

\section{Keywords}

Public Service Motivation, Work Autonomy, Chinese Public Servant

\section{Introduction}

Recently, with the restructuring of government administration in China, the whole society proposes a higher request of service-oriented government as well as service-oriented public servant. However, on the other hand, there have been corruption cases during the process of economic transition in China. Due to an eight-point guideline for fighting bureaucracy and formalism and rejecting extravagance among party members, the new anticorruption policy, off-thebooks income of some public servants has declined and restriction of power has been reinforced. As a result, some of public servants apply for resignation. Aware of this phenomenon, more and more scholars turn to study the public service motivation and find how to improve it inside public servants. But few studies focus on autonomy. This study tries to find the relationship between work autonomy and public service motivation and enrich the theory of public service motivation.

\section{Theoretical Background}

\subsection{Public Service Motivation}

Rainey [1] is considered a starting point to study public service motivation. $\mathrm{He}$ 
studied the reward preferences among public and private managers to search the service ethic. Perry and Wise [2] defined public service motivation as an individual's predisposition to respond to motives grounded primarily or uniquely in public institutions and organizations. And they pointed out that a variety of rational, norm-based, and affective motives appear to be primarily or exclusively associated with public service. After that, Perry [3] initially attempted to develop a scale to test public service motivation, based on an exploratory result, a 24item scale with four subdimensions. The four subdimensions are attraction to policy making, commitment to public interest, compassion and self-sacrifice. Coursey and Pandey [4] refined those four subdimensions into three: attraction to policy making, commitment to public interest, and compassion. Brewer [5] took an intensive research technique called Q-methodology to examine the motives and identify four distinct conceptions of public service motivation: individuals holding these conceptions are referred to as samaritans, communitarians, patriots and humanitarians. According to Kim and Vandenabeele [6], the relationships between PSM and its dimensions show that it is more reasonable to define PSM as a formative construct. Public service motivation has formative dimensions and it is formed as a combination of attraction to public participation, commitment to public values, compassion, and self-sacrifice.

Studies of antecedents of public service motivation have been taken for several years. For instance, Perry [7] [8] investigated the relationship of PSM to five sets of correlates: parental socialization, religious, professional identification, political ideology, and individual demographic characteristics. After a series of research, Perry [8] proposed a process theory of public-service motivation. According to Perry's study, public service motivation is influenced by four critical variables: sociohistorical context, motivational context, individual characteristics and behavior, which is embedded in Bandura's [9] conception of reciprocal causal relationships among three factors: environmental influences, cognitive and other personal factors, and behavior. He called it triadic reciprocal determinism. The findings from Moynihan and Pandey [10] support the role of sociohistorical context, showing that public service motivation is strongly and positively related to level of education and membership in professional organizations. The results also underscore the significant influence of organizational institutions, indicating that red tape and length of organizational membership are negatively related to public service motivation, whereas hierarchical authority and reform efforts have a positive relationship. In China, scholars also conducted research on antecedents of public service motivation. Xianbao Ye [11] found that gender, age, organizational roles have effect on public service motivation.

\subsection{Work Autonomy}

In early research, work autonomy is considered falls in category of work control. Scholars [12] who study on work control thinks that low sense of work control 
or work autonomy has negative effect on work initiative and work enthusiasm. Turner and Lawrence [13] thought that work autonomy is a subdimension of work control and defined it as "the amount of discretion the worker is expected to exercise in carrying put assigned work activities". Hackman and Oldham [14] thought that work autonomy is a dimension of work characteristics. They defined it as "the degree to which the job provides substantial freedom independence and discretion to the individuals in scheduling the work and in determining the procedure to be used in carrying it out". But they defined work autonomy and work independence as the same conception at the same time. So Breaugh [15] provided the most widely accepted definition of work autonomy: "the degree of control or discretion a worker is able to exercise with respect to work methods, work scheduling, and work criteria". And he pointed out that work autonomy includes work method autonomy, work scheduling autonomy and work criteria autonomy.

\section{Hypotheses Development}

\section{Work Autonomy and Public Service Motivation}

According to work autonomy and public service motivation, there have been related research shows that work autonomy can affect public service motivation. Deci and Gagne M [16] found that social-contextual factors that promote feelings of autonomy and competence enhance intrinsic motivation. They also argued that the needs for competence and autonomy underlie intrinsic motivation. According to cognitive evaluation theory in self-determination theory, individual differences in people's orientations toward the initiation and regulation. Controlling environment makes people feel that work is out of their control, which can lead to low work motivation. Work autonomy reflects low level of control. According to this:

Hypothesis. Work autonomy is significantly and positively correlated to public service motivation.

\section{Measure and Method}

In terms of quite sophisticated measurement tool in research of work autonomy, and public service motivation, this study adopts questionnaire in the literature based on their reliability, validity and proper length. The test of reliability and validity of questionnaire is taken before data analysis.

\subsection{Public Service Motivation}

Perry [3] developed a scale and proposed, based on his exploratory result, a 24item scale with four subdimensions. Coursey and Pandey [4] refine those four subdimensions into three: attraction to policy making, commitment to public interest, and compassion. There has been widely verified that Coursy and Pandey's questionnaire with 10 questions has satisfied reliability and validity. In this test, in terms of Chinese culture, 8 of the 10 questions are adopted to form a 
proper public service motivation scale with 5-point Likert scoring method.

In terms of reliability, the Cronbach's alpha of this scale is 0.7. In addition, according to Table 1, the initial analysis of the scale structure with AMOS showed a good model fit. Therefore, this scale can be used to measure PSM.

\subsection{Work Autonomy}

This research takes use of the measurement of work autonomy by Breaugh [15], including work method autonomy, work scheduling autonomy and work criteria autonomy. After removing some questions for a better reliability and validity, this adopts measurement scale of work autonomy within 6 questions and 5-point Likert scoring method.

In terms of reliability, the Cronbach's alpha of this scale is 0.8 . In addition, In addition, according to Table 2, the initial analysis of the scale structure with AMOS showed a good model fit. Therefore, this scale can be used to measure work autonomy.

\subsection{Data Analysis Method}

This study will verify the hypothesis through regression analysis result. So this research takes use of softwares named SPSS 21.0 and AMOS 18.0 for reliability, correlation and regression data analysis.

\section{Data Collection}

A questionnaire survey of public servant form Shandong Province, Beijing, Sichuan Province and Hunan Province constitutes the sample. The sample consists of many public sectors such as the party committee, government, court, industrial and commercial bureau, tax department, education sector, health and family planning department and prison administration. The questionnaire takes 2 basic variables including work autonomy, public service motivation and demographic variables such as gender, age, occupation level job rank and seniority. 500 questionnaires are distributed, 410 of them are collected and 382 questionnaires are valid.

\section{Results}

\section{Work Autonomy and Public Service Motivation}

According to the Table 3, work autonomy can positively predict public service

Table 1. Results of PSM Scale Model Fit.

\begin{tabular}{ccccccccc}
\hline Fit index & $\chi^{2} / \mathrm{df}$ & RMR & NFI & RFI & IFI & TLI & CFI & RMSEA \\
\hline Fit indices & 6.54 & 0.05 & 0.82 & 0.75 & 0.84 & 0.78 & 0.84 & 0.11 \\
\hline
\end{tabular}

Table 2. Results of Work Autonomy Scale Model Fit.

\begin{tabular}{ccccccccc}
\hline Fit index & $\chi^{2} / \mathrm{df}$ & RMR & NFI & RFI & IFI & TLI & CFI & RMSEA \\
\hline Fit indices & 4.69 & 0.04 & 0.93 & 0.89 & 0.95 & 0.91 & 0.95 & 0.09 \\
\hline
\end{tabular}


Table 3. The Regression Analysis of Work Autonomy to Public Service Motivation.

\begin{tabular}{|c|c|c|c|c|c|}
\hline & \multicolumn{2}{|c|}{ Model 1} & \multicolumn{2}{|c|}{ Model 2} \\
\hline & & Beta & $\mathrm{t}$ & Beta & $\mathrm{t}$ \\
\hline \multirow{5}{*}{$\begin{array}{l}\text { Control } \\
\text { Variable }\end{array}$} & Gender & -0.02 & -0.47 & -0.02 & -0.55 \\
\hline & Marriage & -0.01 & -0.28 & -0.01 & -0.26 \\
\hline & Education & 0.03 & 0.48 & 0.04 & 0.63 \\
\hline & Age & 0.02 & 0.28 & 0.03 & 0.30 \\
\hline & Job rank & 0.09 & 1.26 & 0.09 & 1.21 \\
\hline \multirow{5}{*}{ Independent Variable } & Seniority & 0.04 & 0.42 & 0.02 & 0.23 \\
\hline & Monthly salary & -0.16 & $-2.18^{*}$ & -0.162 & $-2.21^{*}$ \\
\hline & Work autonomy & & & 0.17 & $3.54^{* *}$ \\
\hline & $\mathrm{R}^{2}$ & \multicolumn{2}{|c|}{0.01} & \multicolumn{2}{|c|}{0.04} \\
\hline & Adjusted $\mathrm{R}^{2}$ & \multicolumn{2}{|c|}{-0.004} & \multicolumn{2}{|c|}{0.026} \\
\hline
\end{tabular}

note: ${ }^{*} \mathrm{p}<0.05 ;{ }^{* *} \mathrm{p}<0.01$ (two-tailed test).

motivation to a significant degree $(\beta=0.17, \mathrm{p}<0.001)$. That is to say, the higher work autonomy, the stronger public service motivation. So hypothesis can be verified.

\section{Discussion}

This study finds that work autonomy can predict public service motivation positively. That is to say, when the level of work autonomy is low, the level of public service motivation is low. When the level of work autonomy is high, the level of public service motivation is high. From practical perspectives, when public servants are at high level of autonomy in their works, their motive to serve the public is strong. If at low level of autonomy, their motive is weak correspondingly. So if we want to improve the level of public service motivation of Chinese servants, we should consider improving their work environment such as work autonomy. But in Chinese public services system, it is difficult to simply change the work autonomy due to the existing public service system. In the future, more study should be done to find how to improve public servants' work autonomy level as well as not to break the previous rules and regulations.

\section{Conclusion}

According to the result, the data analysis outcome shows that work autonomy can predict public service motivation positively. We can improve public servants' public service motivation by providing more work autonomy. Although work autonomy is hard to change significantly in short time in Chinese government, it is still meaningful to find possible path and mechanism to improve public service motivation through variables related to autonomy.

\section{Limitations and Future Research}

A potential limitation of this study is that work autonomy only explains $2.6 \%$ of 
variance in public service motivation, so work autonomy doesn't have significant prediction of public service motivation. Public service motivation is an implicit variable and is probably influenced by other factors. In the future research, we expect to reveal more factors that can not only influence public service motivation but also build in-depth models that involve mediate and moderate factors to study work autonomy and public service. For example, further studies can bring more behavioral variables or outcome variables, such as job crafting and job burnout.

\section{References}

[1] Ainey, H.G. (1982) Reward Preferences Among Public and Private Managers: In Search of the Service Ethic. American Review of Public Administration, 16, 288302. https://doi.org/10.1177/027507408201600402

[2] Perry, J.L. and Wise, L.R. (1990) The Motivational Bases of Public Service. Public Administration Review, 50, 367-373. https://doi.org/10.2307/976618

[3] Perry, J.L. (1996) Measuring Public Service Motivation: An Assessment of Construct Reliability and Validity. Journal of Public Administration Research \& Theory, 6, 5-22. https://doi.org/10.1093/oxfordjournals.jpart.a024303

[4] Coursey, D.H. and Pandey, S.K. (2007) Public Service Motivation Measurement: Testing an Abridged Version of Perry's Scale. Administration \& Society, 39, 547568. https://doi.org/10.1177/0095399707303634

[5] Brewer, G.A., Selden, S.C. and Facer, R.L. (2000) Individual Conceptions of Public Service Motivation. Public Administration Review, 60, 254-264. https://doi.org/10.1111/0033-3352.00085

[6] Kim, S. and Vandenabeele, W. (2010) A Strategy for Building Public Service Motivation Research Internationally. Public Administration Review, 70, 701-709.

https://doi.org/10.1111/j.1540-6210.2010.02198.x

[7] Perry, J.L. (1997) Antecedents of Public Service Motivation. Journal of Public Administration Research \& Theory, 7, 181-197. https://doi.org/10.1093/oxfordjournals.jpart.a024345

[8] Perry, J.L. (2000) Bringing Society In: Toward a Theory of Public-Service Motivation. Journal of Public Administration Research \& Theory, 10, 471-488. https://doi.org/10.1093/oxfordjournals.jpart.a024277

[9] Bandura, A. (1986) Social Foundation of Thought and Action: A Social Cognitive Theory. Journal of Applied Psychology, 56, 11-18.

[10] Moynihan, D.P. and Pandey, S.K. (2007) The Role of Organizations in Fostering Public Service Motivation. Public Administration Review, 67, 40-53. https://doi.org/10.1111/j.1540-6210.2006.00695.x

[11] Ye, X. and Lai, G. (2011) Public Service Motivation: Measurement, Comparation and Influence-Based on the Analysis of the Questionnaire Survey on Samples from Fujian Province. Chinese Public Administration, No. 8, 107-111.

[12] Parker, S.K., Jackson, P.R. and Wall, T.D. (1993) Autonomous Group Working within Integrated Manufacturing: A Longitudinal Investigation of Employee Role Orientations. Human-Computer Interaction: Applications and Case Studies, Proceedings of the Fifth International Conference on Human-Computer Interaction, DBLP, 44-49.

[13] Hinrichs, J.R. (1965) Industrial Jobs and the Worker: An Investigation of Response to Task Attributes by Arthur N. Turner; Paul R. Lawrence. American Sociological 
Review, 30, 810-811. https://doi.org/10.2307/2091181

[14] Hackman, J.R. and Oldham, G.R. (1976) Motivation through the Design of Work: Test of a Theory. Organizational Behavior and Human Performance, 16, 250-279.

[15] Breaugh, J.A. (1985) The Measurement of Work Autonomy. Human Relations, 38, 551-570. https://doi.org/10.1177/001872678503800604

[16] Gagné, M. and Deci, E.L. (2005) Self-Determination Theory and Work Motivation. Journal of Organizational Behavior, 26, 331-362. https://doi.org/10.1002/job.322

Submit or recommend next manuscript to SCIRP and we will provide best service for you:

Accepting pre-submission inquiries through Email, Facebook, LinkedIn, Twitter, etc. A wide selection of journals (inclusive of 9 subjects, more than 200 journals)

Providing 24-hour high-quality service

User-friendly online submission system

Fair and swift peer-review system

Efficient typesetting and proofreading procedure

Display of the result of downloads and visits, as well as the number of cited articles Maximum dissemination of your research work

Submit your manuscript at: http://papersubmission.scirp.org/

Or contact jss@scirp.org 